\title{
Evaluation of Iris Color Stability in Ocular Prosthesis
}

\author{
Ricardo César dos REIS \\ Reinaldo Brito e DIAS \\ Jose Carlos Mesquita CARVALHO \\ Department of Surgery, Prosthesis and Maxillofacial Traumatology, \\ Dental School, University of São Paulo, São Paulo, SP, Brazil
}

\begin{abstract}
Accurate iris reproduction in the fabrication of ocular prosthesis in order to match the remaining eye is a key factor to mask the loss and achieve an esthetic outcome for anophthalmic patients. This study evaluated the stability of acrylic paints used for replicating iris color in ocular prostheses by the analysis of two factors: the temperature of the acrylic resin polymerization cycle during prosthesis fabrication and the incidence of sun light, which is the main photodegrading agent undermining the longevity of ocular prostheses. An accelerated aging assay was used for both analyses. Specimens simulating the prosthetic iris in the colors blue, yellow, black, brown and green were fabricated, and were submitted to a colorimetric reading before and after undergoing the thermal conditions of acrylic resin polymerization. Next, the specimens were submitted to an artificial accelerated aging assay with ultraviolet radiation A and weekly colorimetric readings during a 3-week period. The color change $\left(\Delta \mathrm{E}^{*}\right)$ values for the four specimens painted with the same color paint were averaged and the resulting values were considered for statistical analysis. Levine's test and Student's t-test were used to analyze the influence of the temperature of the polymerization cycle during prosthesis fabrication on the color stability of each acrylic resin paint. Friedman's test for three dependent samples was used for analysis of color photodegradation as function of time. Significance level was set at 0.05 for all analyses. It was observed that, after the action of the temperature of the polymerization cycle, alteration above clinically acceptable level of $\Delta \mathrm{E}^{*}>3.3$ was observed only for the yellow color. After the accelerated aging assay, there were statistically significant differences $(\mathrm{p}<0.05)$ as a function of time in the green, brown, black and blue colors. Changes were clinically acceptable for the brown and black colors; slightly above the clinically acceptable limit for the green color; and significantly high and impracticable from a clinical standpoint for the blue color. There was no statistically significant differences ( $p>0.05)$ for the yellow color, which presented color change only a little above the clinically acceptable limit. In conclusion: 1 . Only the yellow color presented alterations above the clinically acceptable levels after the polymerization cycle; 2 . After accelerated aging, there was no changes in the yellow color above the clinically acceptable levels; 3 . For the green color, degradation was significant and slightly above the clinically acceptable levels; 4 . The black, brown and blue colors presented significant alterations as function of time; the alterations of the brown and black colors were within acceptable clinical levels, while the blue color presented a more accentuated degradation over time.
\end{abstract}

Key Words: ocular prosthesis, iris painting, color stability.

\section{INTRODUCTION}

The rehabilitating treatment by the placement of ocular prostheses has occupied a significant space in the field of Oral and Maxillofacial Prosthesis. This is mainly because of the great incidence of ocular losses due to pathological reasons or traumatic injuries resulting from physical assault and traffic accidents, which are directly associated with the increasing levels of urban violence observed recently (1).

The eye is an even organ and so its reproductions is challenging. The ocular prosthesis must be as similar as possible to the remaining eye, mainly regarding the iris, which determines the color of the patient's eyes. Several studies (2-4) proposing different iris painting techniques ratify the concern with the fidelity in prosthetic reproduction, using several types of paper, paints and pigments to simulate the iris button.

Another relevant factor to be considered in this type of rehabilitating treatment is the short duration of ocular prostheses, which determines successive changes throughout life. This need increases the demand for the service and represents a shortcoming to the patients', especially those who live far way from the Oral and 
Maxillofacial services. This limitation in the durability of ocular prosthesis is directly related to the photodegradation of the colors of the materials used in iris painting. Studies with accelerated aging and colorimetric evaluation have demonstrated the instability of some colors of pigments and paints under the action of ultraviolet radiation (5-9).

The assessment of color stability under radiation action can improve the esthetic outcome for anophthalmic patients and provide a more detailed understanding of the limitating factors to the longevity of ocular prosthesis. Therefore, this study evaluated the stability of acrylic paints used for replicating iris color in ocular prostheses by the analysis of two factors: the temperature of the acrylic resin polymerization cycle during prosthesis fabrication and the incidence of sun light, which is the main photodegrading agent undermining the longevity of ocular prostheses.

\section{MATERIAL AND METHODS}

Metallic rectangular specimens $(7.5 \times 15 \times 2 \mathrm{~cm})$ were prepared for this study. The base of special flasks sized $20 \times 30 \mathrm{~cm}$ was filled with type II dental plaster (Herodent; Vigodent, São Paulo, SP, Brazil) up to $10 \mathrm{~mm}$ from the upper limit. After seeting, the base layer was isolated with Lyzanda ( Lyzanda Produtos Odontológicos Ltda, São Paulo, SP, Brazil) and filling of the flasks was complemented with special Durone type IV dental stone (Dentsply Indústria e Comércio Ltda., Petrópolis, RJ, Brazil). The metallic specimens were positioned and the flasks were closed.

After the complete setting of the type IV stone layer, the metallic specimens were deflasked, the stone was isolated again and either colorless or sclera acrylic resin (Clássico; Artigos Odontológicos Clássico Ltda. São Paulo, SP, Brazil) was packed. The flasks were closed, pressed and subjected to the polymerization cycle recommended by the manufacturer. Twenty-four hours after comlpete resin setting, the acrylic resin specimens were deflasked and trimmed to remove excesses. The same procedures were repeated obtaining 20 colorless and 20 sclera rectangular-shaped acrylic resin specimens.

As the next step, one side of each of the 20 colorless acrylic resin plates were painted with Acrilex acrylic paint (Acrilex Ltda, São Bernardo do Campo, SP, Brazil) in the colors blue, yellow, brown, green and black. Painting was performed in three layers, always waiting the complete drying a the previous layer to apply a new one. The acrylic resin plates were previously sand-blasted to incrase the adherence of the paint.

The 20 colorless resin plates were attached to the sclera resin plates with a quick-setting cyanoacrylate ester adhesive (Super Bonder ${ }^{\mathbb{B}}$ Instant Adhesive; Locite, Rocky Hill, CT, USA). Subsequently, the junction between the plates was sealed with the same adhesive.

In the literature, the assembly of the specimens to simulate an ocular prosthesis is usually performed by the polymerization of acrylic plates in contact to each other. This chemical process, activated by the polymerization cycle temperature, causes the decomposition of the benzoyl peroxide molecules (10), before the specimens undergo the accelerated aging process. Since in the present study the specimens were assembled by joining polymerized acrylic plates with a cyanoacrylate adhesive, the curing temperature was simulated before the artificial aging assay and the physical effects of temperature in color degradation were evaluated. Using a colorimeter (Minolta CR-300; Minolta Corp., Ramsey, NJ, USA), the specimens were subjected to an initial scanning before and a second scanning after the polymerization cycle.

Next, the specimens were subjected to an accelerated aging assay in a ultraviolet (UV) chamber (Equilam Indústria e Comércia Ltda, Diadema, SP, Brazil). The aging protocol had the duration of 3 weeks totalizing $504 \mathrm{~h}$ with 4 -h cycles of UVA radiation at $60^{\circ} \mathrm{C}$ followed by $4 \mathrm{~h}$ of condensation at $50^{\circ} \mathrm{C}$ in agreement with the guidelines recommended by ASTM 154 (American Society Testing for Materials ) $(7,8,11,12)$. The accelerated aging assay was caried out at the Corrosion Laboratory of the Institute of Technological Researches, São Paulo, SP, Brazil. Colorimetric scannings were accomplished in the same way as described above in the first, second and third week of accelerated aging assay, always in the same region of the specimen to avoid inaccuracies and obtain measures of the three coefficients of the CIE LAB (L*, a* and $\left.b^{*}\right)$ (11)

\section{Statistical Analysis}

The data obtained in this study were processed using the SPSS 12.0 software (SPSS Inc., Chicago IL, USA). The color change $\left(\Delta \mathrm{E}^{*}\right)$ values for the four specimens painted with the same acrylic resin paint 
color were averaged and the resulting values were considered for statistical analysis.

To analyze the influence of the temperature of the polymerization cycle during prosthesis fabrication on color stability of each acrylic resin paint, the Levine's test was used for variance comparisons and the Student's t-test for independent samples was used for average comparison. Friedman's test for three dependent samples was used for analysis of color photodegradation as function of time since the same prototypes were evaluated in three different moments. The level of significance was set at 0.05 for all analyses.

The average of $\Delta \mathrm{E}^{*}$ values between four specimens of the same color was used as parameter for the tests. $\Delta \mathrm{E}^{*}$ values below 3.3 were considered clinically acceptable, as established in previous studies on esthetic dental restorations $(7,8,12,13)$.

\section{RESULTS}

Analyzing the effect of the polymerization cycle temperature on color stability, it was observed that alteration slightly above the clinically acceptable level occurred only for the yellow color $\left(\Delta \mathrm{E}^{*}=3.65\right)$. For the brown, blue, green and black colors, $\Delta \mathrm{E}^{*}$ values were 2.38, 1.16, 1.39 and 1.06, respectively (Fig. 1).

Analyzing the effect of photodegradation, the yellow color did not present statistically significant color variation during the experiment $(\mathrm{p}=0.779) . \Delta \mathrm{E}^{*}$ values values were 5.47, 4.41 and 4.43 in the first, second and third week, respectively (Table 1). For the blue color, there was statistically significant difference over time $(p=0.02) . \Delta E^{*}$ values values were 19.50 in the first,
21.73 in second and 24.68 in the third week (Table 1). For the brown color, significant difference $(\mathrm{p}=0.03)$ as also observed as time passed in the experiement. In the first week, $\Delta \mathrm{E}^{*}$ value was 1.48 , increasing to 1.85 in the second week and to 1.53 in the third week (Table 1). Degradation of the green color over time was also statistically significant $(\mathrm{p}=0.050) . \Delta \mathrm{E}^{*}$ values in the first, second and third weeks were 3.46, 3.55 and 4.86, respectively (Table 1 ). The $\Delta \mathrm{E}$ values for the black color were 1.91, 2.14 and 2.04 in the first, second and in the third week, respectively, with statistical significance among the results $(\mathrm{p}=0.039)$ (Table 1).

\section{DISCUSSION}

The evident functional, esthetic and psychological benefits of the rehabilitation by the placement an ocular prosthesis have motivated the constant investi-

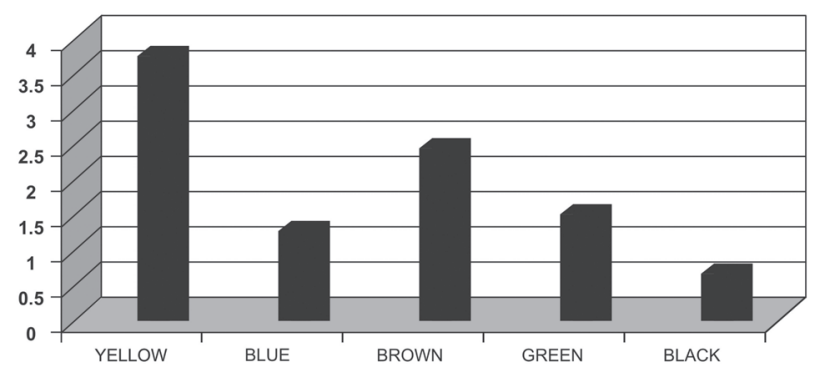

Figure 1. Color change $\left(\Delta \mathrm{E}^{*}\right)$ among the types after thermal conditions of the polymerization cycle.

Table 1. Friedman test for among the times matched samples $(n=4)$ for yellow, blue, brown, green and black colors.

\begin{tabular}{|c|c|c|c|c|c|c|c|c|c|c|}
\hline & \multicolumn{2}{|c|}{ Yellow } & \multicolumn{2}{|c|}{ Blue } & \multicolumn{2}{|c|}{ Brown } & \multicolumn{2}{|c|}{ Green } & \multicolumn{2}{|c|}{ Black } \\
\hline & $\begin{array}{c}\text { Mean } \\
\pm \mathrm{SD}\end{array}$ & $\begin{array}{l}\chi^{2 / p} \\
\text { value }\end{array}$ & $\begin{array}{c}\text { Mean } \\
\pm \mathrm{SD}\end{array}$ & $\begin{array}{l}\chi^{2 / p} \\
\text { value }\end{array}$ & $\begin{array}{c}\text { Mean } \\
\pm \mathrm{SD}\end{array}$ & $\begin{array}{l}\chi^{2 / p} \\
\text { value }\end{array}$ & $\begin{array}{c}\text { Mean } \\
\pm \mathrm{SD}\end{array}$ & $\begin{array}{l}\chi^{2 / p} \\
\text { value }\end{array}$ & $\begin{array}{l}\text { Mean } \\
\pm \mathrm{SD}\end{array}$ & $\begin{array}{l}\chi^{2} / \mathrm{p} \\
\text { value }\end{array}$ \\
\hline $1 \mathrm{wk}$ & $\begin{array}{c}5.47 \pm \\
2.29\end{array}$ & & $\begin{array}{c}19.50 \pm \\
0.59\end{array}$ & & $\begin{array}{c}1.48 \pm \\
0.46\end{array}$ & & $\begin{array}{c}3.46 \\
\pm 0.36\end{array}$ & & $\begin{array}{c}1.91 \pm \\
0.21\end{array}$ & \\
\hline $2 \mathrm{wks}$ & $\begin{array}{c}4.41 \pm \\
0.78\end{array}$ & $\begin{array}{l}0.50 / \\
0.78\end{array}$ & $\begin{array}{c}21.73 \pm \\
0.43\end{array}$ & $\begin{array}{l}8.00 / \\
0.02\end{array}$ & $\begin{array}{c}1.85 \pm \\
0.50\end{array}$ & $\begin{array}{l}6.39 / \\
0.03\end{array}$ & $\begin{array}{c}3.55 \\
\pm 0.40\end{array}$ & $\begin{array}{l}6.00 / \\
0.05\end{array}$ & $\begin{array}{c}2.14 \pm \\
0.16\end{array}$ & $\begin{array}{l}6.50 / \\
0.04\end{array}$ \\
\hline 3 wks & $\begin{array}{c}4.43 \pm \\
0.52\end{array}$ & & $\begin{array}{c}24.68 \pm \\
0.63\end{array}$ & & $\begin{array}{c}1.50 \pm \\
0.51\end{array}$ & & $\begin{array}{c}4.86 \pm \\
0.50\end{array}$ & & $\begin{array}{c}2.04 \pm \\
0.11\end{array}$ & \\
\hline
\end{tabular}


gation on the improvement of prosthetic techniques.

The reproduction of the prosthetic iris is a fundamental and critical stage during the construction of ocular prosthesis. It might be accomplished with all technical and artistic resources available. Authors are unanimous in highlight that matching the remaining eye is determinant to mask the loss and achieve an esthetic outcome for anophthalmic patients $(2,14,15)$.

Several modifications in prosthetic iris painting techniques have been proposed, using several types of paints, pigments and papers, such as white cardboard with watercolor paint $(3,16)$ or black cardboard $(14)$. Acrylic (17) and oil paint (4) have been indicated for prosthetic iris painting. Macedo (15) suggested the use of Carmem type paper with watercolor paint, while black color paper with the same paint were used in other studies $(14,17)$. Some authors do not indicate painting on paper disks for iris painting in ocular prosthesis. Dietz (18) used a celluloid acetate disk. Direct painting on an acrylic disk allowed verifying the color and the direct positioning in the wax-plastic piece (17). According to Budin and Lavergne (19), previously painted glass iris produces esthetically superior results compared to all other techniques.

Photodegradation is the main photodegrading agent undermining the longevity of ocular prostheses. This alteration occurs mainly due to the action of UV radiation, specifically UVC rays, which are responsible for $95 \%$ of sunlight incidence during the Summer (20).

The colorimetric scanning allows quantifying color alteration using a mathematical equation expressed by $\Delta \mathrm{E}^{*}$ and obtained with the variation of the three coefficients $(\mathrm{L}, \mathrm{a}$ and $\mathrm{b})$. It consists of a mechanism that simulates the cerebral reading of the colors using the CIE L*a*b* system (12).

In this study, the specimens were submitted to an initial colorimetric scanning and a second scanning after undergoing the thermal coditions of the polymerization cycle. In the colorimetric analysis after temperature action, the yellow color presented the highest level of color instability, with $\Delta \mathrm{E}^{*}$ value of 2.79 , followed by the brown $\left(\Delta \mathrm{E}^{*}=2.38\right)$, green $\left(\Delta \mathrm{E}^{*}=1.39\right)$, blue $\left(\Delta \mathrm{E}^{*}=\right.$ 1.16) and black $\left(\Delta \mathrm{E}^{*}=1.05\right)$ colors (Fig. 1 and Table 1$)$.

The artificial aging test partially indicates the behavior of a material under certain conditions. However, it is widely used for development and control of different properties of materials. Artificial aging is achieved in a laboratory environment, using an accelerated aging chamber with lamps that simulate the sunlight and the weather condensation cycles (11).

Comparing the weekly evaluations within the 3week accelerated aging test period, the yellow color showed no statistically significant variation over time ( $\mathrm{p}=0.78$ ), comparing the $\Delta \mathrm{E}^{*}$ values obtained in the first, second and third weeks (Table 1). The blue color presented statistically significant color change $(p=0.02)$ as a function of time. A progressive increase of $\Delta \mathrm{E}^{*}$ values occurred from the first week to the third week (Table 1). These results are in agreement with those of a previous work (6) that compared water-soluble acrylic paint with automotive acrylic resin using UVB and observed great color change for the blue pigment. Evaluating microwave-polymerized ocular prosthesis, Fernandes et al. (7) verified a instable behavior of the blue pigment in the five paint types. Kawabata (8) also observed color stability below the clinically acceptable level for the blue color in the three pigments evaluated for characterization in two types of sclera resin.

Changes in the brown, green and black color stability over time were also statistically significant $(p=0.03)$ and occurred progressively, with a lower $\Delta \mathrm{E}^{*}$ value in the first week and a higher $\Delta \mathrm{E}^{*}$ value in the last third week (Table 1).

The results obtained for the brown color are consistent with those of a previous study comparing automotive paint with acrylic paint, using simulated aging with UVB radiation (6). In the present study, significant differences in the brown color were observed among the three evaluated periods, but with a small final variation of color compared to the clinically acceptable level. By clinical experience, the colors black and brown are predominant in iris with chestnut brown tones, present in the great majority of the Brazilian population. A small variation in the black color was also obtained for the same pigment when comparing automotive paint with acrylic paint, according to D' Almeida (6).

The findings of this study support the following conclusions: 1. after the thermal action of the polymerization cycle, only the yellow color presented alteration above the clinically acceptable level; 2 . After accelerated aging, there was no significant difference in yellow color changes over time or alterations above the clinically acceptable level; 3. For the green color, degradation was significant and slightly above the clinically acceptable level; 4 . Likewise, the black, brown and blue colors presented significant changes as func- 
tion of time; however, while the alterations of the brown and black colors were within an acceptable clinical level, the blue color presented a more accentuated degradation during the 3 weeks of evaluation.

\section{RESUMO}

A fiel reprodução da íris do olho remanescente através da pintura na confecção da prótese ocular é fator fundamental no resultado estético e na dissimulação da perda para os pacientes afetados. Decidiu-se, então, avaliar a estabilidade das cores da tinta acrílica utilizada na pintura da mesma, sob a ação de dois fatores: a temperatura do ciclo de polimerização da resina acrílica e a incidência da luz solar, principal agente de fotodegradação que compromete a longevidade das próteses oculares, através de teste de envelhecimento acelerado. Foram assim, confeccionados corpos de prova simulando a íris protética, nas cores azul, amarelo, preto, marrom e verde, submetidos a uma leitura colorimétrica inicial e outra após as condições térmicas do ciclo de polimerização. Posteriormente os mesmos foram testados durante três semanas através de ensaio de envelhecimento acelerado artificialmente com radiação ultravioleta A e leituras colorimétricas semanais. Através dos valores da alteração de cor $\left(\Delta E^{*}\right)$ foi obtida uma média para as quatro amostras pintadas com a mesma cor e os valores resultantes foram submetidos à análise estatística. Os testes de Levine e $t$ de Student foram utilizados para analisar a influência da temperatura do processo de polimerização na estabilidade de cada cor utilizada na fabricação das próteses. O teste de Friedman para três amostras dependentes foi usado para analisar a degradação de cor em função do tempo. O nível de significância foi de 0,05 para todas as análises. Após a ação da temperatura do ciclo de polimerização, observou-se que somente na cor amarelo ocorreu alteração acima do nível clinicamente aceitável $(p<0,05)$. Após o ensaio de envelhecimento, ocorreram diferenças estatisticamente significantes em função do tempo nas cores verde, marrom, preto e azul. A variação de cor ocorreu em níveis considerados clinicamente aceitáveis para as cores marrom e preto; levemente acima dos níveis clinicamente aceitáveis para a cor verde; e em níveis elevados, inviáveis clinicamente para a cor azul. Na cor amarelo não houve diferenças estatisticamente significantes ( $p>0,05)$, com alteração apenas um pouco acima do limite considerado clinicamente aceitável. Em conslusão: 1. Somente a cor amarelo apresentou alteração acima dos níveis clinicamente aceitáveis após o ciclo de polimerização; 2 . Após o envelhecimento artificial, não houve alterações na cor amarelo acima dos níveis clinicamente aceitáveis; 3 . Para a cor verde, a degradação foi significante e um pouco acima dos níveis clinicamente aceitáveis; 4 . As cores preto, marrom e azul apresentaram diferenças significantes em função do tempo; as alterações das cores marrom e preto foram em níveis clinicamente aceitáveis, enquanto a cor azul apresentou um elevado índice de degradação de cor em todo tempo.

\section{REFERENCES}

1. Coas VR, Neves AC, Rode SM. Evaluation of the etiology ocular globe atrophy or loss. Braz Dent J 2005;16:243-246.
2. Murgo DOA, Neves ACC. Development of a scale of iris color. APCD Magazine 2001;55:421-425.

3. Murphey PJ, Pitton RD, Schlossberg L, Harris LW. The development of acrylic eye prosthesis at The National Naval Medical Center. J Am Dent Assoc 1945;32:1227-1244.

4. Brown KE. Fabrication of an ocular prosthesis. J Prosthet Dent 1970;24:225-235.

5. Alves MCAP, Carvalho JCM. Ocular prosthesis - evaluation of the esthetics and of the stability of the color of the painted iris with acrylic paint and oil paint. RPG 2004;11:57-60.

6. D' Almeida NF. Evaluation of the employed paints color stability in the iris painting in ocular prosthesis [Master's degree Dissertation]. São José dos Campos: UNESP Dentistry University; 1999

7. Fernandes AUR, Goiato MC, Santos DM, Ribeiro PP, Guiotti AM. Chromatic alteration of the artificial iris painting in function of accelerated aging, drying method, paint and color. Bras Oral Res 2005;19:143.

8. Kabawata SC. Evaluation of the sclera color stability in ocular prosthesis [Master's degree Dissertation]. São Paulo: USP Dentistry University; 2006.

9. Silva DP, Carvalho JCM. Ocular prosthesis: preliminary study of different paints for iris painting. Rev Odontol Univ S Paulo 1994;8:71-76.

10. Anusavice KJ. Phillips - Dental Materials. 11 ed. Chapter 22. Rio de Janeiro: Elsevier; 2005. p. 688-691.

11. Brennan P, Fedor C. Sunlight, UV \& accelerated weathering. Technical Bulletin LU-0822. The Q-Panel Lab Products; 1994. LU-0822; p. $1-7$.

12. Lemon JC, Chambers MS, Jacobsen ML, Powers JM. Color stability of facial prostheses. J Prosthet Dent 1995;74:613618.

13. Koksal T, Dikbas I. Color stability of different denture teeth materials against various staining agents. Dent Mater J 2008;27:139-144.

14. Raizada K, Rani D. Ocular Prosthesis. Cont Lens Anterior Eye 2007;30:152-162.

15. Macedo FF. Iris painting in ocular prosthesis. APCD Magazine 1982;36:528-533.

16. Meissner E. Ocular Prosthesis of acrylic material. Rev Dent Chile 1950;42:319-322.

17. Rezende JRV, Macedo FF, Miracca R, Fonseca EP. Making and rebasing in ocular prosthesis. In: Ocular prosthesis Fonseca EP (Editor). 1st ed. São Paulo: Panamed Editorial; 1987.

18. Dietz VH. The all plastic artificial eye. Illinois Dent J 1945;14:246-248.

19. Budin $P$, Lavergne P. Prostheses oculaire en resina synrhetique. Rev Franc Odontoestomat 1961;8:981-988.

20. Okuno E, Vilela MAC. Ultraviolet radiation: characteristics and effects. 1st ed. São Paulo: Editora Livraria da Física, 2005 . 